\title{
ARAŞTIRMA/RESEARCH
}

\section{Ortopedi ameliyatlarında perioperatif hipotermi insidansı ve risk etmenleri}

\author{
Incidence of perioperative hypothermia in orthopaedic surgery and risk factors
}

Ayfer Yurdadur Duman', Emel Yilmaz ${ }^{2}$

${ }^{1}$ Celal Bayar Üniversitesi Sağlık Bilimleri Enstitüsü, Cerrahi Hastalıkları Hemşireliği Anabilim Dalı, Manisa, Turkey

${ }^{2}$ Celal Bayar Üniversitesi Manisa Sağlık Yüksekokulu, Manisa, Turkey

\section{Cukurova Medical Journal 2016;41(4):687-694.}

\begin{abstract}
Purpose: The purpose of this research is to determine the incidence with causing factors such as demographic characteristics, type of surgery, type of anesthesia, operation time and operating room temperature of hypothermia during perioperative period of orthopedic surgery.
\end{abstract}

Material and Methods:This research was planned to be defining cross-sectional, which included 116 patients that were operated by orthopedic surgery lasting longer than 60 minutes in a university hospital in western Turkey. During operation and post-op recovery, each patient's body temperature, vitals and room temperature was measured every 20 minutes. Patients with body temperature lower than $36^{\circ} \mathrm{C}$ were categorized as hypothermia.

Results: $31.9 \%$ of patients underwent replacement surgery and $35.3 \%$ had general anesthesia. $69.8 \%$ of the patients were in hypothermia during the 60 th minute of the operation.This research has found that during orthopedic surgery, patients' body temperatures dropped $0.66^{\circ} \mathrm{C}$ during the first hour of the operation and $1.54^{\circ} \mathrm{C}$ at the end of operation. When intraoperative 0-60th minutes measurements were compared, body temperature, pulse, systolic and diastolic blood pressure values were found to be statistically significant. It was found that 60 th minute measurements were significantly lower than 0 th minute measurements.

Conclusion:Inadvertent hypothermia is seen frequently in orthopedic patients.It is recommended that frequent body temperature monitoring and warming patients should be routinely practiced during orthopedic surgery.

Key words: Hypothermia, perioperative, orthopedic surgery, anesthesia
Öz

Amaç: Araştırma ortopedi ameliyatlarında perioperatif dönemde hipotermi insidansı ile demografik özellikler, ameliyat türü, anestezi türü, ameliyat süresi ve ameliyathane sıcaklığı gibi hipotermiyi etkileyen etmenleri belirlemek amacıyla yapılmıştır.

Gereç ve Yöntem: Tanımlayıcı-kesitsel türdeki bu araştırmaya Türkiye'nin Batı bölgesindeki bir üniversite hastanesinde ortopedik ameliyat yapılan ve ameliyat süresi 60 dakikadan uzun olan 116 hasta alınmıştır. Hastaların ameliyat sirasinda ve derlenme ünitesinde 20 dakika aralar ile vücut sıcaklığı, vital bulguları ve ortam sıcaklığ1 ölçülerek kayıt edilmiştir. $36^{\circ} C^{\prime}$ nin altındaki vücut sıcaklıkları hipotermi olarak kabul edilmiştir.

Bulgular: Hastaların \%31.9'una endoprotez ameliyatı yapılmış ve \%35.3’üne genel anestezi uygulanmıştır. Ameliyatın 60. dakikasında $\% 69.8$ oranında hipotermi görülmüştür. Araştırma sonucunda ortopedi ameliyatlarında hastaların vücut sıcaklıklarında ilk bir saatte $0.66{ }^{\circ} \mathrm{C}$, ameliyat sonunda $1.54{ }^{\circ} \mathrm{C}$ lik bir düşme saptanmıştır. Intraoperatif 0. dakika ile 60. dakikalardaki ölçüm değerleri arasındaki değişim karşılaştırıldığında vücut sıcaklığı, nabız, sistolik ve diyastolik kan basıncı değerleri arasında istatistiksel olarak anlamlı fark bulunmuştur. 60. dakikada bu ölçüm değerlerinde 0 . dakikaya göre düşme belirlenmiştir.

Sonuç: İstenmeyen hipotermi ortopedi hastalarında sık olarak görülmektedir. Hipoterminin önlenmesi amacı ile ameliyat sırasında vücut sıcaklığı takiplerinin sık yapılması ve hastaların 1sitılmasinın rutin bir uygulama olarak kullanılması önerilmektedir.

Anahtar kelimeler: Hipotermi, perioperatif, ortopedi ameliyat1, anestezi 


\section{GİRİ̧̧}

Normal vücut sıcaklığı $36^{\circ} \mathrm{C}-37.7^{\circ} \mathrm{C}$ arasında değişmektedir ${ }^{1}$. İstenmeyen hipotermi; ameliyat öncesi dönemden başlayarak ameliyat sonrası döneme kadar geçen süre içinde vücut sıcaklığının $36^{\circ} \mathrm{C}$ 'nin altına düşmesidir ${ }^{2-5}$. Ameliyat sürecinde istenmeyen hipotermi $\% 70$ oraninda görülmektedir ${ }^{5,6}$. Preoperatif açlik, anestetik ilaçlar, soğuk ameliyathane, kullanılan soğuk sıvılar, dokuların açıkta kalması gibi nedenlere bağlı olarak 1s1 düzenleme mekanizması bozularak hipotermi gelişmektedir2,6-8. Ameliyat sürecindeki hipotermi sonucunda iyileşme sürecinde uzama, kan kaybında artma, aritmi ya da kardiyak arrest, titreme, bağışıklık sisteminde bozulma, yara iyileşmesinde gecikme ve yara enfeksiyonu gelişmesi riski $\operatorname{artar}^{6,9,10}$. Anestezi alan hastalarda ilk 60 dakikada $0.5-1.5^{\circ} \mathrm{C}$ arasinda değişen 1s1 kayb1 görülmektedir. Ameliyat süresi uzadıkça 1s1 kayb1 devam eder ${ }^{3,10-12}$. ASA II-IV, kadın hastalar, büyük ve orta dereceli cerrahi girişim geçirecek hastalar, 70 yaş üzerindeki hastalar, eşlik eden kronik hastalığ olanlar ve kombine rejyonal ve genel anestezi uygulanan hastalarda hipotermi gelişme riski yüksektir ${ }^{10}$. Hipotermi gelişiminin önlenmesi ile hastada oluşabilecek komplikasyonlar azaltılarak hastanın iyileşme süreci hızlanacaktır ${ }^{8}$.

Cerrahi süreçte sıcaklık kontrolünün sağlanması ve sürdürülmesinde perioperatif bakım veren anestezi ekibi ve hemşirelere büyük sorumluluk düşmektedir. Doğru girişimler ve hasta izleme teknikleri ile istenmeyen hipotermi insidansını azaltabilir. Perioperatif bakım veren anestezi ekibi ve hemşireler perioperatif dönemde hastanın normal vücut sıcaklığını devam ettirmek için aktif ve pasif 1sıtma yöntemlerini kullanarak hipotermi gelişimini azaltabilir. Sicaklık kontrolünün sağlanması ve sürdürülmesi fiziksel bakım ve konforla ilgili olması nedeniyle anestezi ekibi ve hemşirelere büyük sorumluluk düşmektedir ${ }^{3,8,13}$. Tüm bunlardan yola çıkılarak bu araştırmada ortopedi hastalarında oluşan hipotermi sorununa açıklık getirmek, bu konuya dikkat çekmek ve olası koruma önlemlerini geliştirmeye 1şı1k tutmak amaçlanmıştır.

\section{GEREÇ VE YÖNTEM}

Araştırma ortopedi ameliyatlarında perioperatif dönemde hipotermi insidansı ile demografik özellikler, ameliyat türü, anestezi türü, ameliyat süresi ve ameliyathane sicaklığ1 gibi hipotermiyi etkileyen etmenleri belirlemek amacıyla yapılmıştır. Çalışma tanımlayıcı ve kesitsel tiptedir.

Araştırma 30 Mart 2014 -30 Haziran 2014 tarihleri arasında Celal Bayar Üniversitesi Hafsa Sultan Hastanesi ortopedi ameliyathanesinde yapılmışır. Araștırmanın örnek büyüklüğü; Aksu ve arkadaşlarının $^{14}$ çalışmasındaki hipotermi sıklığı (\%45.7) dikkate alınarak Epi İnfo programında \%5 sapma ve $\% 95$ güvenilirlik düzeyinde en küçük örnek büyüklüğü 108 kişi olarak hesaplanmış ve araştırmaya 116 hasta alınmıştır.

Araştırmaya; 18 yaşın üzerinde, ameliyat öncesinde ateşi olmayan, miksödem, hipertioidi ve dolaşım bozukluğu bulunmayan, yapılan fizik muayene ve tetkikler sonucu ortopedi ameliyatı yapilan ve araştırmaya katılmaya gönüllü hastalar dahil edilmiştir.

Veri toplamak amacıyla aşağıdaki formlar kullanılmıştır.

1. Kişisel bilgi formu: Verilerin toplanmasında kişisel bilgi formu kullanılmıştır. Bireylerin yaş, cinsiyet, beden kitle indeksi (BKI), medeni durum, eğitim durumu, gelir düzeyi ve çalışma durumu gibi demografik özellikleri ile ilgili sorulardan oluşmaktadır. Ayrıca bu formda hastaların tanısı, şikayet süresi, kronik hastalık varlığ1 ve ilaç kullama durumuna ilişkin sorular da yer almaktadir.

2. Perioperatif kayıt formu: Hastaların anestezi ve cerrahi girişime bağlı değişkenlerinin (ASA, ameliyathane sıcaklığ1, ameliyat türü, anestezi türü, kanama miktar1, verilen sıv1 ve miktarlar1, ameliyat süresi) hipotermi riskini belirlemeye yönelik hazırlanmış sorulardan oluşmaktadır. Ayrıca hastaların vücut sıcaklığ1 ve diğer ölçüm değerlerinin (nabız, sistolik ve diyastolik kan basınc1 ve O2 saturasyonu) kayıt edildiği bölüm yer almaktadir.

Araştırma verileri yasal izinler (Etik Kurul onayı, hastalardan bilgilendirilmiş onam) alındıktan sonra araştırmaya kabul edilme ölçütlerine uyan ve araştırmaya katılmaya gönüllü hastalardan elde edilmiştir. Ortopedi ameliyathanesinde beklenen girissim süresi 60 dakikadan uzun olan hastalar çalş̧maya dahil edilmiştir. Hastalara ilişkin bazı bilgiler yaş, cinsiyet, BKİ, ameliyattan önce aç kalma süresi, ameliyat türü, ameliyat süresi, anestezi süresi, verilen solüsyonların miktarı, türü, sıcaklığı, kanama miktarı, anesteziden uyanma süresi, ameliyat 
Sırasında 1sıtma uygulanıp uygulanmadığı araştırmacı tarafindan geliştirilen bir çizelgeye kayıt edilmiştir. Postoperatif dönemde hastaların derlenme ünitesine giriş vücut sıcaklıkları ölçülmüştür. Derlenme ünitesinden taburcu olma süresi, titreme olup olmadığ1 ve derlenme ünitesinde kalma süresi kaydedilmiştir.

Ameliyathane sıcaklığı her vakada kaydedilmiştir. Araştırmaya alınan her hastada; vücut sıcaklığı, nabız, solunum, $\mathrm{O}_{2}$ satürasyonu, sistolik ve diyastolik kan basıncı ölçümü intraoperatif dönemde her 20 dakikada bir, postoperatif dönemde ise aynı parametreler derlenme ünitesinde 20 dakika aralar ile tekrar ölçülmüştür. Bu veriler araștırmacı tarafından hazırlanan forma kayıt edilmiștir. Ölçümlerde kullanılan tüm araç gerecin kalibrasyonu yapılmış ve tüm hastalarda aynı ölçüm araçları kullanılmıştır. Vücut sıcaklığı ölçümleri araştırmacı tarafından timpanik membrandan aynı sicaklık ölçer cihaz (Genius 2, infrared timpanik termometre, Mansfield, Amerika Birleşik Devletleri), nabız, $\mathrm{O}_{2}$ saturasyonu, sistolik ve diyastolik kan basincı noninvaziv olarak anesthesia monitorü (Datex Ohmeda, GE Healthcare Helsinki, Finland) ile ölçülmüştür. $\mathrm{Bu}$ çalışmada vücut sıcaklığının $36^{\circ} \mathrm{C}$ 'nin altında olması hipotermi olarak kabul edilmiştir. Ayrıca ameliyathane sıcaklığı da ELITE marka (Hong Kong, China) sıcaklık ve nem ölçer ile ölçülmüştür.

\section{İstatistiksel analiz}

Verilerin analizi SPSS 15.0 (SPSS Inc., Chicago, IL, ABD) paket programında yapılmıştır. Çalışmadan elde edilen verilerin değerlendirilmesinde tanımlayıcı istatistikler (sayı, yüzde, ortalama $\_$standart sapma, minimum ve maksimum), ki kare testi, Fisher'in kesin ki kare testi, Student t testi ve Paired t testi kullanılmıştır. Sonuçlar \%95'lik güven aralığında ve anlamlılık $\mathrm{p}<0.05$ düzeyinde değerlendirilmiştir.

\section{BULGULAR}

Tablo 1'de görüldüğü gibi araştırmaya alınan hastaların \%51.7'sini 38 yaş ve altı olan [(yaş

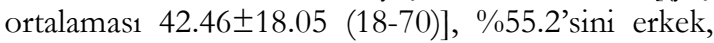
$\% 51.7$ 'sini normal kilolu [(BKI ortalamasi $\left.25.30 \pm 3.50 \quad \mathrm{~kg} / \mathrm{m}^{2} \quad(18.42-38.10)\right], \quad \% 55.2^{\prime}$ sini ortaokul ve üzeri eğitim düzeyinde olan ve $\%$ 60.3’ünü evli hastalar oluşturmaktadır.
Tablo 2'de görüldüğü gibi araştırmaya alınan hastaların \%47.4'ünü ekstremite ameliyatı olan, \%64.7'sini epidural/spinal anestezi alan, \%73.3'ünü ameliyat sirasinda lokal $(20 \mathrm{~cm}$ ve altı) 1slaklik olan ve \%69.8'ini ameliyatın 60. dakikasında vücut s1caklıklar1 $36.0 \mathrm{oC}$ ve alt1 olan hastalar oluşturmaktadır.

Araştırmaya katılan hastaların preoperatif aç kalma süresi $9.269 \pm 1.48$ (2.00-14.00) saat, ameliyathanede bekleme süresi $17.29 \pm 6.65$ (10.00-30.00) dakika, ameliyat süresi 91.94 34.59 dakika (60.00-180.00),

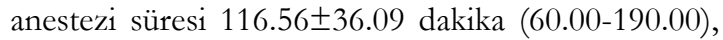
ameliyathane sicaklığ ortalamasi $21.01 \pm 1.18 \mathrm{OC}$ (18.20-23.80) ve derlenme ünitesi sıcaklık ortalaması $23.72 \pm 0.53$ OC (22.00-25.00) dir.

Grafik 1 de görüldüğü gibi intraoperatif 0 . saatte vücut sıcaklığı ortalamas1 $36.47{ }^{\circ} \mathrm{C}$ iken, 60. dakikada $35.81^{\circ} \mathrm{C}$ ve 180 . dakikada $34.93^{\circ} \mathrm{C}$ olarak saptanmıştır. 0 ile 60 . dakika arasında vücut sicaklığında $0.66^{\circ} \mathrm{C}^{\prime}$ lik, ameliyat sonunda ise ilk dakikaya göre $1.54{ }^{\circ} C^{\prime}$ lik bir düşme oluşmuştur. Postoperatif dönemde derlenme ünitesinde vücut sicaklığ1 0. dakikada $35.69{ }^{\circ} \mathrm{C}$ iken, 40. dakikada $36.25^{\circ} C^{\prime}$ 'ye ulaşmıştır.

Tablo 3'te intraoperatif 60 . dakikadaki vücut sıcaklığ1 değerleri ile değişkenlerin karşılaştırılması verilmiştir. Buna göre 38 ve altı yaş grubunda olan hastalarda daha fazla hipotermi oluşmuştur ve aradaki fark istatistiksel olarak anlamlıdır $\left(\chi^{2}=4.268, \mathrm{p}=0.039\right)$. BKİ daha düşük hastalarda daha fazla hipotermi görülmüştür ve aradaki fark anlamlıdır ( $\mathrm{t}=-2.606$, $\mathrm{p}=0.010)$. Epidural/spinal anestezi alan hastalarda hipotermi daha fazla oluşmuştur. Ancak aradaki fark sinırda saptanmıştır $\quad\left(\chi^{2}=3.837, \quad \mathrm{p}=0.050\right)$. Ameliyathane sıcaklığının daha düşük olduğu hastalarda hipotermi daha fazla olmasına rağmen aradaki fark anlamlı bulunmamıştır ( $\mathrm{t}=-1.178$, $\mathrm{p}=0.241$ ). Kanama miktar1 fazla olan, IV siv1 ve kan ürünlerinin daha fazla kullanıldığı ve ameliyat sırasında daha fazla 1slaklığı olan hastalarda daha fazla hipotermi oluşmasına karşıı aradaki fark istatistiksel olarak anlamsızdır (sırası ile; $\mathrm{t}=0.510$, $\mathrm{p}=0.611 ; \mathrm{t}=1.857, \mathrm{p}=0.066 ; \mathrm{t}=1.235, \mathrm{p}=0.231$; $\mathrm{p}=1.000)$. Hipotermisi olan hastalarda anesteziden uyanma süresi uzun ve ameliyat sonrasi titreme daha fazla görülmesine rağmen aradaki fark anlamsız olarak belirlenmiştir $\left(t=0.107, p=0.915 ; \chi^{2}=0.370\right.$, $\mathrm{p}=0.543)$. 
Tablo 1. Araştırma grubunu oluşturan hastaların tanıtıcı özellikleri

\begin{tabular}{|c|c|c|}
\hline Değişkenler & Sayı & Yüzde \\
\hline \multicolumn{3}{|l|}{ Yaş grubu } \\
\hline 38 ve alt1 & 60 & 51.7 \\
\hline 39 ve üzeri & 56 & 48.3 \\
\hline Yaş, Ort. \pm SS (Min.-Maks.) & \multicolumn{2}{|c|}{$42.46 \pm 18.05(18-70)$} \\
\hline \multicolumn{3}{|l|}{ Cinsiyet } \\
\hline Erkek & 64 & 55.2 \\
\hline Kadın & 52 & 44.8 \\
\hline \multicolumn{3}{|l|}{ Beden kitle indeksi (BKİ) } \\
\hline $\begin{array}{l}\text { Normal kilolu } \\
\left(18.5-24.9 \mathrm{~kg} / \mathrm{m}^{2}\right)\end{array}$ & 60 & 51.7 \\
\hline $\begin{array}{l}\text { Fazla kilolu } \\
\text { (25kg/m² ve üzeri) } \\
\text { Beden kitle indeksi } \\
\text { Ort. } \pm \text { SS (Min.-Maks.) }\end{array}$ & \multicolumn{2}{|c|}{$25.30 \pm 3.50 \mathrm{~kg} / \mathrm{m}^{2}(18.42-38.10)$} \\
\hline \multicolumn{3}{|l|}{ Ĕgitim düzeyi } \\
\hline İlkokul ve altı & 52 & 44.8 \\
\hline Ortaokul ve üzeri & 64 & 55.2 \\
\hline \multicolumn{3}{|l|}{ Medeni durum } \\
\hline Evli & 70 & 60.3 \\
\hline Bekar/dul/ayrı yaşayan & 46 & 39.7 \\
\hline
\end{tabular}

Beden Kitle İndeksi $18.5-24.9 \mathrm{~kg} / \mathrm{m}^{2}$ : Normal kilolu, Beden Kitle İndeksi $25 \mathrm{~kg} / \mathrm{m}^{2}$ ve üzeri: Fazla kilolu

Ort.: Ortalama; SS: Standart sapma; Min.: Minimum; Maks.: Maksimum.

Tablo 2. Araştırma grubunu oluşturan hastaların ameliyat özellikleri

\begin{tabular}{|c|c|c|}
\hline Değişkenler & Say1 & Yüzde \\
\hline \multicolumn{3}{|l|}{ Ameliyat Türü } \\
\hline Femur Ameliyat1 & 24 & 20.7 \\
\hline Endoprotez & 37 & 31.9 \\
\hline Ekstremite Ameliyat1 & 55 & 47.4 \\
\hline \multicolumn{3}{|l|}{ Anestezi Türü } \\
\hline Genel Anestezi & 41 & 35.3 \\
\hline Epidural/Spinal Anestezi & 75 & 64.7 \\
\hline \multicolumn{3}{|l|}{ Ameliyatta Islaklık Durumu } \\
\hline Lokal (20cm ve altı) & 85 & 73.3 \\
\hline Geniş (20cm ve üstü) & 18 & 15.5 \\
\hline Yok & 13 & 11.2 \\
\hline \multicolumn{3}{|l|}{ 60. Dakikada Hipotermi } \\
\hline $36.0^{\circ} \mathrm{C}$ ve alt1 & 81 & 69.8 \\
\hline $36.1^{\circ} \mathrm{C}$ ve üstü & 35 & 30.2 \\
\hline \multicolumn{3}{|l|}{ Titreme Durumu } \\
\hline Var & 84 & 72.4 \\
\hline Yok & 32 & 27.6 \\
\hline Süreler & Ort. \pm SS & Min.-Maks. \\
\hline Preoperatif aç kalma süresi (saat) & $9.269 \pm 1.48$ & $2.00-14.00$ \\
\hline Ameliyathanede bekleme süresi (dakika) & $17.29 \pm 6.65$ & $10.00-30.00$ \\
\hline Ameliyat süresi (dakika) & $91.94 \pm 34.59$ & $60.00-180.00$ \\
\hline Anestezi süresi (dakika) & $116.56 \pm 36.09$ & $60.00-190.00$ \\
\hline \multicolumn{3}{|l|}{ S1caklık Değerleri } \\
\hline Ameliyathane $\left({ }^{\circ} \mathrm{C}\right)$ & $21.01 \pm 1.18$ & $18.20-23.80$ \\
\hline Derlenme ünitesi $\left({ }^{\circ} \mathrm{C}\right)$ & $23.72 \pm 0.53$ & $22.00-25.00$ \\
\hline
\end{tabular}

Ort.: Ortalama; SS: Standart sapma; Min.: Minimum; Maks.: Maksimum. 
Grafik 1. Hastaların perioperatif dönemdeki vücut sıcaklığı ortalamalarına göre dağılımı

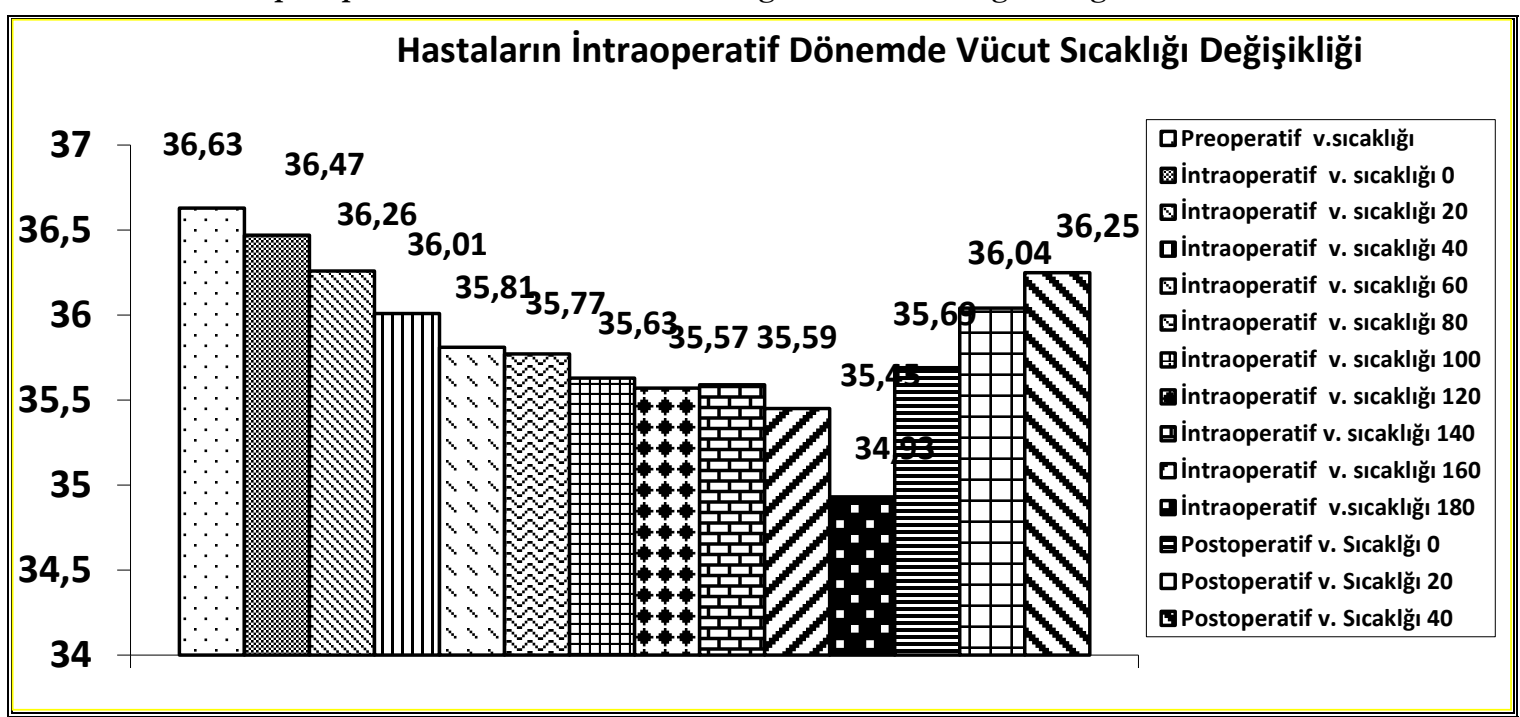

Tablo 3. Hastaların intraoperatif 60. dakikadaki vücut sıcaklığı ile değişkenlerin karşılaştırılması

\begin{tabular}{|c|c|c|c|}
\hline Değişkenler & Hipotermi $(n=81)$ & Normotermi $(n=35)$ & Test istatistiği \\
\hline \multicolumn{4}{|l|}{ Yaş } \\
\hline 38 ve altı n(\%) & $47(78.3)$ & $13(21.7)$ & \multirow{2}{*}{$\chi^{2}=4.268, p=0.039 c$} \\
\hline 39 ve üzeri $n(\%)$ & $34(60.7)$ & $22(39.3)$ & \\
\hline \multicolumn{4}{|l|}{ Anestezi türü } \\
\hline Genel anestezi $n(\%)$ & $24(58.5)$ & $17(41.5)$ & \multirow[t]{2}{*}{$\chi^{2}=3.837, p=0.050^{c}$} \\
\hline Epidural/spinal anestezi n(\%) & $57(76.0)$ & $18(24.0)$ & \\
\hline BKİ & $24.76 \pm 3.37$ & $26.56 \pm 0.37$ & $\mathrm{t}=-2.606, \mathrm{p}=0.010^{\mathrm{a}}$ \\
\hline Ameliyathane sıcaklığ1 & $20.93 \pm 1.05$ & $21.21 \pm 1.42$ & $\mathrm{t}=-1.178, \mathrm{p}=0.241^{\mathrm{a}}$ \\
\hline IV s1vı miktarı & $1635.80 \pm 656.75$ & $1400.00 \pm 553.07$ & $\mathrm{t}=1.857, \mathrm{p}=0.066^{\mathrm{a}}$ \\
\hline Kan ürünü miktarı & $576.92 \pm 879.54$ & $211.11 \pm 78.17$ & $\mathrm{t}=1.235, \mathrm{p}=0.231_{\mathrm{a}}$ \\
\hline Kanama miktarı & $98.40 \pm 54.87$ & $92,57 \pm 60.16$ & $\mathrm{t}=0.510, \mathrm{p}=0.611^{\mathrm{a}}$ \\
\hline Ameliyatta 1slaklık & $72(\% 69.9)$ & $31(\% 30.1)$ & $\mathrm{p}=1.000^{\mathrm{b}}$ \\
\hline Anesteziden uyanma süresi & $12.54 \pm 4.55(\mathrm{n}=26)$ & $12.40 \pm 2.67(\mathrm{n}=15)$ & $\mathrm{t}=0.107, \mathrm{p}=0.915^{\mathrm{a}}$ \\
\hline Ameliyat sonras1 titreme $\mathrm{n}(\%)$ & $60(71.4)$ & $24(28.6)$ & $\chi^{2}=0.370, p=0.543^{c}$ \\
\hline
\end{tabular}

${ }^{a}=$ Student $\mathrm{t}$ testi, $\mathrm{b}=$ Fisher'in Kesin Ki Kare testi, ${ }^{c}=$ Ki Kare Testi

Tablo 4. Hastaların intraoperatif 0 . dakika ile 60. dakikadaki ölçüm değerlerinin karşılaştırılması

\begin{tabular}{|c|c|c|c|c|}
\hline İntraoperatif ölçümler & $\mathbf{N}$ & Ort. \pm SS & $\mathbf{t}$ & $\mathrm{p}^{*}$ \\
\hline İntraoperatif 0 . dk vücut sıcaklı̆g 1 & 116 & $36.47 \pm 0.34$ & \multirow[t]{2}{*}{22.162} & \multirow[t]{2}{*}{0.000} \\
\hline İntraoperatif 60 . dk vücut s1cakllğ1 & 116 & $35.82 \pm 0.48$ & & \\
\hline İntraoperatif $0 . \mathrm{dk}$ nabiz & 116 & $74.19 \pm 12.26$ & \multirow[t]{2}{*}{3.597} & \multirow[t]{2}{*}{0.000} \\
\hline İntraoperatif $60 . \mathrm{dk}$ nabiz & 116 & $72.21 \pm 11.64$ & & \\
\hline İntraoperatif 0. dk sistolik kan basinc1 & 116 & $127.78 \pm 18.39$ & \multirow[t]{2}{*}{4.044} & \multirow[t]{2}{*}{0.000} \\
\hline Intraoperatif $60 . \mathrm{dk}$ sistolik kan basınc1 & 116 & $123.76 \pm 17.63$ & & \\
\hline İntraoperatif $0 . \mathrm{dk}$ diyastolik kan basınc1 & 116 & $71.46 \pm 8.97$ & \multirow[t]{2}{*}{6.131} & \multirow[t]{2}{*}{0.000} \\
\hline İntraoperatif 60. dk diyastolik kan basınc1 & 116 & $68.54 \pm 7.51$ & & \\
\hline İntraoperatif $0 . \mathrm{dk}$ solunum & 116 & $16.98 \pm 2.57$ & \multirow[t]{2}{*}{-0.823} & \multirow[t]{2}{*}{0.412} \\
\hline İntraoperatif $60 . \mathrm{dk}$ solunum & 116 & $17.16 \pm 2.34$ & & \\
\hline İntraoperatif $0 . \mathrm{dk}_{2}$ saturasyonu & 116 & $99.21 \pm 1.36$ & \multirow[t]{2}{*}{-0.961} & \multirow[t]{2}{*}{0.339} \\
\hline İntraoperatif $60 . \mathrm{dk} \mathrm{O}_{2}$ saturasyonu & 116 & $99.09 \pm 1.17$ & & \\
\hline İntraoperatif $0 . \mathrm{dk}$ ameliyathane sıcaklığ1 & 116 & $20.93 \pm 1.17$ & \multirow[t]{2}{*}{-0.182} & \multirow[t]{2}{*}{0.856} \\
\hline İntraoperatif $60 . \mathrm{dk}$ ameliyathane sicaklığ1 & 116 & $20.94 \pm 1.12$ & & \\
\hline
\end{tabular}


Tablo 4 'de görüldüğü gibi intraoperatif 0 . dakika ile 60. dakikalardaki ölçüm değerleri arasındaki değişim karşılaştırıldığında vücut sıcaklı̆̆ı, nabız, sistolik ve diyastolik kan basınc1 değerleri arasında istatistiksel olarak anlamlı fark saptanmıştır $(\mathrm{p}<0.05) .60$. dakikada bu ölçüm değerlerinde 0 . dakikaya göre düşme saptanmıştır. Diğer değişkenlerde istatistiksel olarak anlamlı fark belirlenmemiştir ( $\mathrm{p}>0.05)$.

\section{TARTIŞMA}

Perioperatif hipotermi anestezik ilaçlar ve cerrahi işleme bağlı olarak ortaya çımaktadır $5,6,11,15,16$. İstenmeyen hipotermi perioperatif dönemde vücut sıcaklığının $36^{\circ} C^{\prime}$ nin altına düşmesidir10. Çalışmada $36{ }^{\circ} C^{\prime}$ 'nin altı hipotermi kabul edilmiş ve sonuçlar da buna göre değerlendirilmiştir.

Ortopedi ameliyatlarında perioperatif dönemde hipotermi insidansı ve etkileyen etmenleri belirlemek amacıyla yapılan bu çalışmada hastalarda ameliyatın birinci saatinde \% \% $\% 9.8$ oranında hipotermi oluşmuştur. Aksu ve arkadaşlarının çalışmasında hipotermi insidası \%45.7 olarak bulunmuştur ${ }^{14}$. Prado ve arkadaşlarının çalışmasında anestezi indüksiyonundan bir saat sonra hastaların \%85.7'inde hipotermi oluştuğu belirtilmiştir ${ }^{17}$. Bu çalışmadaki hipotermi oranı Paulo ve arkadaşlarının çalışmasından düşük, Aksu ve arkadaşlarının çalışmasından yüksek bulunmuştur. Farkın örneklem grubu ile ilişkili olduğu düşünülmektedir. Hipotermiyi önlemeye yönelik alınacak önlemlerin bu oranı azaltmada etkili olacağı düşünülmektedir.

Araştırma grubunu oluşturan hastaların vücut sicakliklarında ilk bir saatte $0.66{ }^{\circ} \mathrm{C}$, ameliyat sonunda 1.54 oC’lik bir düşme saptanmıştır. Literatürde anestezi verilmesini takiben ilk bir saat içinde vücut sıcaklığında $0.5-1.5^{\circ} \mathrm{C}$ 'lik bir düşme olduğu belirtilmektedir ${ }^{10-13}$. Bulgularımız literatür ile uygunluk göstermektedir.

Hastaların derlenme ünitesine alındığı 0 . dakikada hipotermi saptanırken 40. dakikada normotermi sağlanmıştır. Postoperatif dönemde hastaların 1sıtılmasının normotermiyi sağlamada etkili olduğu bildirilmiştir ${ }^{15}$. Derlenme ünitesinde hastalar battaniye ile örtülerek 1sı kaybı azaltılmış ve vücut sıcaklıkları arttırılmıştır. Bulgular literatüre paralellik göstermektedir.
Araştırma grubunun ameliyat süresi minimum 60, maksimum 180 dakika olarak belirlenmiştir. Ameliyat ve anestezi süresi uzun olan hastalar daha fazla anestezi almakta ve anestezi süresine bağlı olarak hipotermi oluşumu artmaktadir ${ }^{15}$. Araştırmada ameliyatın 60. dakikasındaki vücut sicaklığ1 ortalamas1 $35.81 \pm 0.48$ oC iken 180 . dakikadaki sıcaklık ortalaması $34.93 \pm 0.65{ }^{\circ} \mathrm{C}$ olarak bulunmuştur. Bulgular literatürü destekler niteliktedir.

Araştırmaya alınan hipotermik hastalarda anesteziden uyanma süresi normotermik olanlardan minimal yüksek olmasına karşın istatistiksel olarak anlamlı fark saptanmamıştır. Literatürde hipotermik hastalarda uyanma süresi ve derlenme ünitesinde kalış süresinin uzadığı bildirilmiştir ${ }^{15}$. Araştırma bulguları literatür ile uygunluk göstermemektedir. Farkın örnekleme grubundaki genel anestezi uygulanan hasta sayisinin az olmasindan kaynaklandığ1 düşünülmektedir.

Araştırma grubunda 38 ve altı yaş grubundaki hastalarda daha fazla hipotermi görülmüştür. Yapılan çalışmalarda ileri yaşın hipotermi oluşumunda risk oluşturduğu belirtilmiştir ${ }^{12,18,19}$. Çalışma bulguları literatürden farklıdır. Farkın örneklem grubu ile ilgili olduğu düşünülmektedir.

Epidural/spinal anestezi uygulanan hastalarda daha fazla hipotermi oluşmuştur. Literatürde genel anestezinin diğer anestezi türlerine göre hipotermi riskini arttırdığ1 belirtilmiştir ${ }^{11,14}$. Farkın araştırma grubundaki hastalara genel anestezi daha az uygulamasından olabileceği görüşündeyiz.

Araştırma grubunda BKI'i düşük hastalarda daha fazla hipotermi oluşmuştur ve aradaki fark anlamlı olarak saptanmıştır. Literatürde beden kitle indeksi düşüklügünün cilt altı yağ dokusunun az olması nedeni ile hipotermi için risk faktörü olduğu bildirilmiştir ${ }^{12,13}$. Fernandes ve arkadaşları ameliyat sırasinda obez hastalarda hipotermi insidansinin obez olmayanlara göre daha az olduğunu belirtmişlerdir ${ }^{20}$. Araştırma bulguları literatüre paraleldir.

Araştırma grubunda daha fazla sıv1 verilen ve kanama miktarı fazla olan hastalarda daha fazla hipotermi görülmesine rağmen aralarındaki fark istatistiksel olarak anlamlı bulunmamıştır. Ameliyat sırasında verilen soğuk sıvıların hipotermi için risk 
faktörü olduğu belirtilmiştir ${ }^{6} .1250$ hastayı içeren 24 çalışmanın incelendiği bir derlemede intraopreratif dönemde kullanılan solüsyonların $37^{\circ} \mathrm{C}-41^{\circ} \mathrm{C}$ arasında isıtılmasının oda sıcaklığında verilen solüsyonlara göre vücut iç sıcaklığını ve titremeyi azalttığ 1 bildirilmiştir ${ }^{21}$. Ameliyat sırasında hastaya verilecek kan ve siviların isttilarak verilmesinin hipotermiyi azaltacağı görüşündeyiz.

Araştırmada ameliyathane sıcaklı̆̆ı ile hipotermi oluşumu arasında istatistiksel olarak anlamlı fark saptanmamıştır. Ortam sıcaklığının hipotermi oluşumunda önemli olduğu ve $21^{\circ} \mathrm{C}$ 'nin altındaki ameliyathanelerde hipotermi riskinin arttığ1 bildirilmiştir ${ }^{3}$. Ameliyathane sicaklığının $21-24^{\circ} \mathrm{C}$ arasında tutulması ile hipotermi oluşumunun azaltılabileceği belirtilmiştir ${ }^{4}$. Araştırmada ameliyathane sıcaklığı literatürde belirtilen sınırlar içinde tutulmuştur.

Araştırma kapsamına alınan hastaların \%4.3'üne 1sıtma uygulanmıştır. İntraoperatif ve postoperatif dönemde hipotermi gelişiminin önlenmesi, gelişebilecek komplikasyonların azaltılması ve hasta konforunun sağlanması açısından önemlidir. Bu amaçla, perioperatif dönem boyunca 1sı kaybını ve hipotermi oluşmasını önlemek ve hastaların beden sıcaklıklarının normal sınırlarda sürdürülmesi için günümüzde aktif ve pasif 1sıtma yöntemleri kullanılmaktadır $8,10,12$. Perioperatif dönemde farkl 1sıtma yöntemlerinin etkinliğinin değerlendirildiğ çalışmalarda 1sıtmanın hipotermiyi önlemede etkili olduğu belirlenmesine karşın ${ }^{22,23}$ intraoperatif dönemde 1sitma yaygin olarak kullanılmamaktadır ${ }^{14,24}$. Bu araştırmada da 1sıtma oranı düşüktür. Isıtmanın önemi ile ilgili gerekli eğitim çalışmalarına başlanmasının büyük önemi olduğu düşünülmektedir.

Araştırma kapsamına alınan ve hipotermisi oluşan hastaların \%71.4'ünde titreme oluşmuştur. Anestezi sonras1 titreme anestezinin yaygin komplikasyonlarından olup, genel anesteziden sonra \%5-65, epidural anesteziden sonra ise yaklaş1k \%30 oranında görüldüğü belirtilmiştir ${ }^{25}$. Literatürde perioperatif hipoterminin titremeye neden olduğu, titremenin oksijen tüketimini arttırarak hipoksi ve asidoz oluşumuna neden olduğu belirtilmiştir ${ }^{9,12,26}$. Ayrıca titreme ile yara yerinin gerilmesine bağlı olarak ameliyat sonrası ağrının arttı̆̆1, cerrahi kanama ve yara yeri enfeksiyonlarının görülme sıklığ1 ile hastanede kalış süresinde artış olduğu bildirilmiştir ${ }^{25}$. Hipotermi oluşumunun önlenmesine yönelik yapılacak düzenlemeler ile titremenin azaltılabileceği görüşündeyiz.

Araştırmada ameliyatın 0 . dakikası ve 60 . dakikasında sistolik ve diyastolik kan basincı ve nabız değerleri arasında fark saptanmıştır. 60. dakikada bu parametre değerleri düşmüştür. Kurz ve arkadaşlarının kolorektal cerrahi hastalarında yaptığ çalışmasında normotermik ve hipotermik hastaların aynı parametre değerleri arasında fark saptanmamıştır ${ }^{27}$. Araştırma bulguları literatürden farklıdır. Farkın yapılan ameliyat türü ile ilişkili olabileceği kanısındayız.

Araştırma sonucunda ortopedi ameliyatlarında hastaların vücut sıcaklı̆̆ında ilk bir saatte $0.66^{\circ} \mathrm{C}$, ameliyat sonunda $1.54{ }^{\circ} \mathrm{C}$ 'lik bir düşme saptanmıştır. Ameliyatın 60. dakikasında \%69.8 oranında hipotermi görülmüştür. İntraoperatif 60. dakikadaki vücut sıcaklığı, nabız, sistolik ve diyastolik kan basınc1 değerlerinde 0 . dakikaya göre düşme saptanmıştır. Diğer değişkenlerde istatistiksel olarak anlamlı fark belirlenmemiştir.

Araştırmadan elde edilen bulgular doğrultusunda; tüm ameliyat geçiren hastalarının olası bir hipotermi nedeniyle vücut sicaklıklarının ve diğer vital bulgularının sık ölçülmesi ve değerlendirilmesi ve ameliyat olacak hastalarının ameliyat öncesinden itibaren hipotermi yönünden korunması önemlidir. Ameliyattan sonra hastalarında, sslak örtülerin çıkartılması, soğuk sıvıların verilmemesi, 1sıtma yöntemlerinin kullanılması, ameliyathane ekibine hipoterminin önemi ve hasta üzerinde meydana getirdiği zararların anlatılması gereklidir. Ameliyat sırasında uygulanan 1sıtma yöntemlerinin anlatılması ve ameliyathane ekibinin bilgi düzeyinin arttırılması ve bu araştırmanın daha farklı ameliyat türlerini de içine alacak daha büyük bir örneklem grubu ile yapılması önerilir.

Bu çalıs̆ma 2014 ynlında Celal Bayar Üniversitesi Sağhlk Bilimleri Enstitüsü Cerrabi Hastaliklar Hemșireligui Anabilim Dah Tezsiz. Yüksek Lisans programinda dönem projesi olarak kabul edilmistir. Ayruca 12-15 Kasim 2015 taribleri arasinda yapılan 9.Ulusal Türk Cerrabi ve Ameliyathane Hemssireliği Kongresinde poster bildiri olarak. sunulmustur.

\section{KAYNAKLAR}

1. Warttig S, Alderson P, Campbell G, Smith AF. Interventions for treating inadvertent postoperative 
hypothermia. Cochrane Database Syst Rev. 2014;11: CD009892: 1-50.

2. ASPAN. Clinical guideline for the prevention of unplanned perioperative hypothermia. J Perianesth Nurs. 2001;16:303-14.

3. Paulikas CA. Prevention of unplanned perioperative hypothermia. AORN 2008;88:358-68.

4. Torossian A. TEMMP (Thermoregulation in Europe Monitoring and Managing Patient Temperature) Study Group. Survey on intraoperative temperature management in Europe. Eur J Anaesthesiol. 2007;24:668-75.

5. Knaepel A. Inadvertent perioperative hypothermia: a literature review. J Perioper Pract. 2012;22:86-90.

6. Burger L, Fitzpatrick J. Prevention of inadvertent perioperative hypothermia. Br J Nurs. 2009;18:11149.

7. Leslie K, Sessler DI. Perioperative hypothermia in the high-risk surgical patient. Best Pract Res Clin Anaesthesiol. 2003;17:485-98.

8. Bolt LB, Stannard D. Thermal insulation for preventing inadvertent perioperative hypothermia. J Perianesth Nurs. 2015;30:427-9.

9. Doufas AG. Consequences of inadvertent perioperative hypothermia. Best Pract Res Clin Anaesthesiol. 2003;17:535-49.

10. Türk Anesteziyoloji ve Reanimasyon Derneği Yönetim Kurulu. Türk Anesteziyoloji ve Reanimasyon Derneği istenmeyen perioperatif hipoderminin önlenmesi rehberi. Turk J Anaesth Reanim. 2013;41:188-90.

11. Sessler DI. Mild perioperative hypothermia. N Engl J Med. 1997;336:1730-7.

12. Hart SR, Bordes B, Hart J, Corsino D, Harmon D. Unintended perioperative hypothermia Ochsner J. 2011;11:259-70.

13. Wagner D. Patient safety chiller: Unplanned perioperative hypothermia. AORN J. 2006;83:473-6.

14. Aksu C, Kuş A, Gürkan Y, Solak M, Toker K. Kocaeli Üniversitesi ameliyathanesi postoperatif hipotermi insidansı araştırması. Turk J Anaesth Reanim. 2014;42:66-70.

15. Feinstein L, Miskiewicz M. Perioperative hypothermia: review for the anesthesia provider. Internet J Anesthesiol. 2009;27:1-8.

16. Warttig S, Alderson P, Campbell G, Smith AF. Interventions for treating inadvertent postoperative hypothermia. Cochrane Database Syst Rev. 2014;20;11: CD009892.

17. Prado CBC, Barichello E, Pires PS, Haas VJ, Barbosa $\mathrm{MH}$. Occurrence and factors associated with hypothermia during elective abdominal surgery. Acta Paul Enferm. 2015;28:475-42.

18. Kongsayreepong S, Chaibundit C, Chadpaibool J, Komoltri C, Suraseranivongse S, Suwannanonda P, et al. Predictor of core hypothermia and the surgical Intensive care unit. Anesth Analg. 2003;96:826-33.

19. Luís C, Moreno C, Silva A, Páscoa R, Abelha F. Inadvertent postoperative hypothermia at postanesthesia care unit: incidence, predictors and outcome. Open J Anesthesiol. 2012;2:205-13.

20. Fernandes LA, Braz LG, Koga FA, Kakuda CM, Módolo NS, de Carvalho LR, et al. Comparison of peri-operative core temperature in obese and nonobese patients. Anaesthesia. 2012;67:1364-9.

21. Campbell G, Alderson P, Smith AF, Warttig S. Warming of intravenous and irrigation fluids for preventing inadvertent perioperative hypothermia (Review). Cochrane Database Syst Rev. 2015;4:CD009891.

22. Kurşun Ş, Dramalı A. Batın ameliyatı yapılan hastalarda postoperatif dönemde elektrikli battaniye ile 1sitmanin yeniden isinma süresine etkisi. Genel Tip Dergisi 2011;21:1-4.

23. Yang HL, Lee HF, Chu TL, Su YY, Ho LH, Fan JY. The comparison of two recovery room warming methods for hypothermia patients who had undergone spinal surgery. J Nurs Scholarsh. 2012;44:2-10.

24. Young VL, Watson ME. Prevention of perioperative hypothermia in plastic surgery. Aesthet Surg J. 2006;26:551-71.

25. Karaaslan D, Öztürk S. Anestezi sonrası titreme ve termoregülasyon. Turkiye Klinikleri J Anest Reanim. 2009; 7:98-104.

26. Torossian A, Bräuer A, Höcker J, Bein B, Wulf H, Horn EP. Preventing inadvertent perioperative hypothermia. Dtsch Arztebl Int. 2015;112:166-72.

27. Kurz A, Sessler D, Lenhartdt R. Perioperative normothermia to reduce the incidence of surgicalwound infection and shorten hospitalization. $\mathrm{N}$ Engl J Med. 1996;334:1209-15. 